\title{
The Role of Platelet Rich Plasma on Healing of Induced Femoral Fracture Fixed With Dynamic Compression Plate in Dogs.
}

Ahmed I.H, Hassan M.M, El-Daharawy M.H, Amina A. Dessouki* and Hashem M.A.

Department of Surgery, Anesthesiology and Radiology and *Department of Pathology, Faculty of Veterinary Medicine. Suez Canal University.

\begin{abstract}
The present study was carried out to evaluate the platelet rich plasma (PRP) as a factor for accelerating bone healing and compared with normal healing in 18 apparently healthy male mongrel dogs based on clinical, radiographic and histopathological findings. Induction of femoral fracture was done in all dogs of both groups, a gap $(0.5 \mathrm{~cm} \times$ $0.5 \mathrm{~cm}$ with the whole depth of the near cortex) was created at the fracture sit bone rongeur and the fracture was fixed with standard dynamic compression plate (DCP) and self taping cortical screws. Dogs were divided into two equal groups, each of 9 dogs. Group I was left as a control. In group II, the gap was packed with autogenous PRP. The results of this study pointed out that PRP slightly improved bone healing.
\end{abstract}

\section{Introduction}

Fractures can be fixed using different types of external and internal fixation devices (Stiffler, 2004 and Baele, 2004). Internal fixation techniques involve intramedullary pins, elastic stable intramedullary nails (ESIN), bone plates, orthopedic wires, and screws (Stephan and Perren, 2002).

The most appropriate bone plate system is the Dynamic Compression Plate (DCP), in which the holes are managed in such a way that they cause compression of the fracture fragments (Roe, 2003). Many types of bone screws exist in veterinary practice. Cortical bone screws used for dense cortical bone as it has less depth between threads and more threads per screw (low pitch) to increase engagement with the bone. Murphy et al. (2001), described other screw types which involve self tapping screws that have a cutting flute on their tip which must completely exit the far cortex.

The clinical application of PRP was considered a breakthrough in acceleration of bone and soft tissue healing. Platelets and the released growth factors they release are essential for regulating the cellular events that follow tissue damage. They adhere, aggregate, form a fibrin mesh, and subsequently 
release a large variety of growth factors and cytokines (Eppley et al., 2004).

The preparation of PRP was done after Stefan and Dimitar (2007) where, the patient's own blood was drawn out in sterile containers, containing $1 \mathrm{ml}$ CPDA-1(Citrate Phosphate Dextrose Adenine Solution) then prepared by two phase centrifugation. The first spin was at $2400 \mathrm{rpm}$ for 10 minutes. With this spin the erythrocytes were separated from platelet poor plasma. The PRP was separated from platelet poor plasma by a second spin at $3600 \mathrm{rpm}$ for 15 minutes and became ready for use.

The aim of this study was to evaluate the ability of PRP to accelerate bone healing based on clinical, radiographic and histopathological examinations.

\section{Materials and Methods}

This study was carried out on 18 mongrel apparently healthy adult male dogs with average body weight $15-18 \mathrm{~kg}$ and age of 12-15 months at the Department of Surgery, Faculty of Veterinary Medicine, Suez Canal University. Food was withheld for 24 hours an water for 6-8 hrs before the operation. Each dog was premedicated with $\mathrm{I} / \mathrm{M}$ injection of chloropromazine hydrochloride (Misr Co. Pharm. Industries, S.A.A) in a dose of $1 \mathrm{mg} / \mathrm{kg}$. The site of operation (lateral aspect of the right thigh) was aseptically prepared, and then general anesthesia was conducted by $\mathrm{I} / \mathrm{V}$ injection of thiopental sodium $2.5 \%$ solution (Sandoz GmbH, Kund, Austria) until the main reflexes were disappeared. The right femur of all animals was experimentally fractured transversally by using a wire saw in the mid-diaphysis under constant cooling with a $0.9 \% \mathrm{NaCl}$ solution with antibiotic, and a gap $(0.5 \mathrm{~cm} 0.5 \mathrm{~cm}$ with the whole depth of the near cortex) was created at the fracture site. Dogs were divided into two equal groups. The induced fracture in dogs of group I (control) was reduced and fixed with DCP and self-taping cortical screws (Fig. 1). In group II, it was fixed as in group I and the gap was packed with PRP (Fig.2) which was prepared after Stefan and Dimitar (2007).

Dogs were clinically examined daily during the study period (12 weeks). The functional disorders of the affected limb during walking were evaluated according to Fox et al. (1995) (Table 1). The data was recorded during the $1^{\text {st }}, 2^{\text {nd }}, 4^{\text {th }}, 6^{\text {th }}$, $8^{\text {th }}, 10^{\text {th }}, 12^{\text {th }}$ weeks after surgery. Radiographs were taken at the $4^{\text {th }}$, $8^{\text {th }}$ and $12^{\text {th }}$ weeks postoperatively.

The bone specimens were obtained from each group at $4^{\text {th }}, 8^{\text {th }}$ and $12^{\text {th }}$ weeks postoperative after euthanasia of dogs using overdose of thiopental sodium. The bone specimens were prepared according to Hobbenaghi et al. (2014).

Data of the present study were analyzed using One-way Analysis 
of Variance (ANOVA) procedures according to Snedecor and Cochran (1989) for testing of significance between the studied groups. Means separation and pair wise comparisons were done by Duncan's Multiple Range test according to Duncan (1955). Statistical analyses were conducted by SPSS for windows (SPSS version 20). Results are considered significant at probability level of 0.05 for each ( $\mathrm{P} \leq 0.05)$.

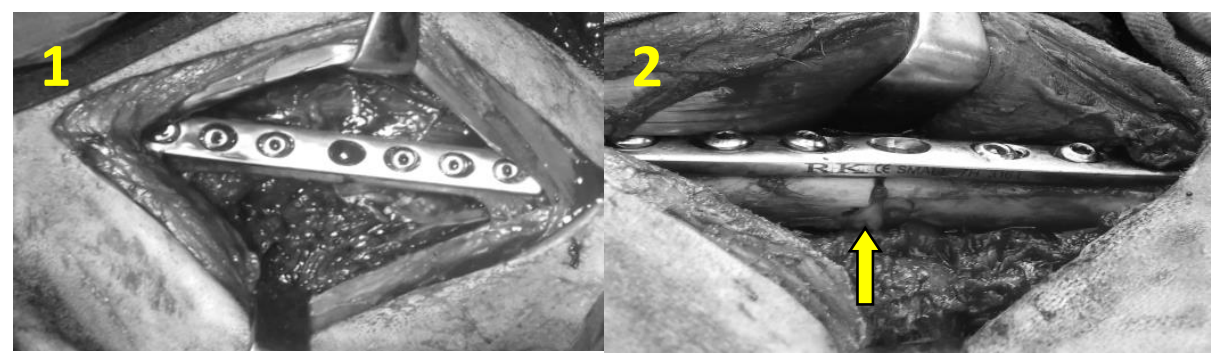

Fig. (1): Showing fixation of the fractured bone with DCP and self-taping cortical bone screws

Fig. (2): Showing packing of platelet rich plasma (yellow arrow) into the induced fracture gap in a dog of group II.

Table (1): Scales of walking during the convalescent period according to Fox, et al. (1995).

\begin{tabular}{|c|l|}
\hline Degree & \multicolumn{1}{|c|}{ Description } \\
\hline $\mathbf{0}$ & Normal attitude in station and walking without lameness. \\
\hline $\mathbf{1}$ & $\begin{array}{l}\text { Difficulties in walking, especially at rapid carriage with fine } \\
\text { lameness. }\end{array}$ \\
\hline $\mathbf{2}$ & Difficulties in walking, intermittent lameness in rapid walking. \\
\hline $\mathbf{3}$ & Evident lameness at every step. \\
\hline $\mathbf{4}$ & The leg pulls out of support in station and in walking, intense pain. \\
\hline
\end{tabular}

\section{Results}

Pronounced lameness with local inflammatory signs (pain, redness, hotness, swelling and tenderness) was visible in all dogs in the first postoperative day. A slight improvement in the degree of lameness was noticed in group II but with no significant difference with dogs of group I on the $6^{\text {th }}$ and $8^{\text {th }}$ weeks postoperatively. On the $10^{\text {th }}$ and $12^{\text {th }}$ weeks postoperatively, group I showed a significant increase in the degree of lameness rather than dogs of group II (Fig.3). On the 4th postoperative week, radiographs of group I showed a mild radiopaque periosteal reaction 
(Fig. 4), while in group II, a moderate radiopaque periosteal reaction and progressive radiopaque endosteal callus was evident (Fig. 5). Mal-union of the fracture as a result of bending of the DCP was clearly obvious in the radiograph of a dog of group II 4 weeks

postoperatively (Fig. 6). On the $8^{\text {th }}$ week, a bridging radiopaque periosteal callus and radiopaque endosteal callus was found between the two fractured ends of the bone in dogs of group I. In group II, radiographs clarified the declination of the fracture line with well developed radiopaque endosteal callus (Fig. 7). On the $12^{\text {th }}$ week, Radiographic films of group I revealed progressed radiopaque periosteal and endosteal reactions with declined fracture line. A very faint fracture line with dense radiopaque endosteal callus was denoted in dogs of group II (Fig. 8). On the $4^{\text {th }}$ week postoperative, microscopic examination of group I revealed a large endosteal callus composed of fairly arranged fibrous connective tissue with many newly formed capillaries and some inflammatory cells with small endosteal callus. Moderately dense connective tissues which form the external and internal callus were seen in group II (Fig. 9). On the $8^{\text {th }}$ week, group I showed mature granulation tissue with collagen fibers on the internal surface of the bone at the fracture site (Fig. 10). In group II, the fracture gap was occluded with a dense properly arranged mature granulation tissue and dispersed cartilaginous cells (Fig. 11). On the $12^{\text {th }}$ week, all of defect spaces in group I occupied by extensive fibrous tissue and small foci of separate bone lamellae found irregularly inbetween (Fig. 12). Group II revealed, very small fracture line with thin bony trabeculae joining each other and intermingled with mature granulation tissue and focal cartilaginous areas (Fig. 13).

\section{Degrees of lameness}

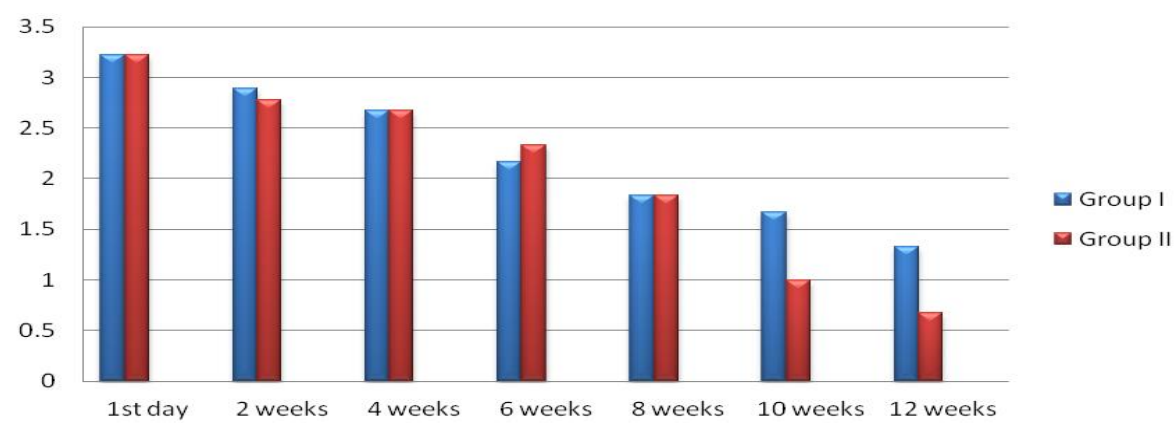

Fig. (3): Degree of lameness (mean ranks $\pm S E$ at different times among the experimental groups) 


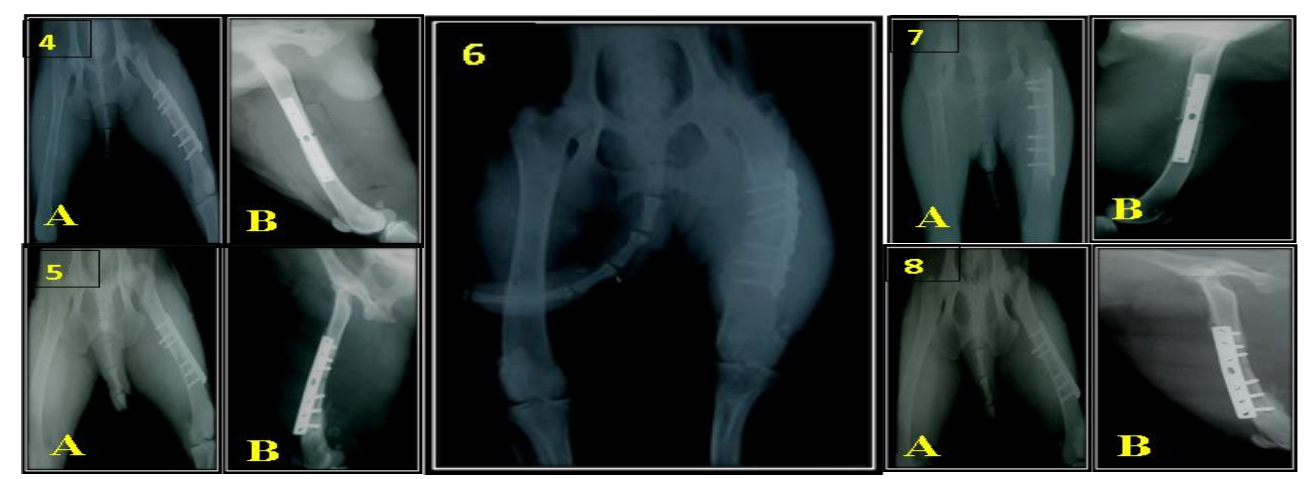

Fig. (4): Antero-posterior (A) and lateral (B) radiographic views in a dog of group I, 4 weeks post operatively showing a clear fracture line with mild radiopaque periosteal reaction.

Fig. (5): Antero-posterior (A) and lateral (B) radiographic views in a dog of group II, 4 weeks postoperatively showing mild radiopaque periosteal reaction and progressive radiopaque endosteal callus.

Fig. (6): Antero-posterior radiographic view in a dog of group II, 4 weeks postoperatively showing bending of the DCP with fracture mal-union.

Fig. (7): Antero-posterior (A) and lateral (B) radiographic views in a dog of group II, 8 weeks postoperatively showing declined fracture line with developed radiopaque endosteal callus.

Fig. (8): Antero-posterior (A) and lateral (B) radiographic views in a dog of group II, 12 weeks postoperatively showing faint radiolucent fracture line with dense radiopaque endosteal callus.

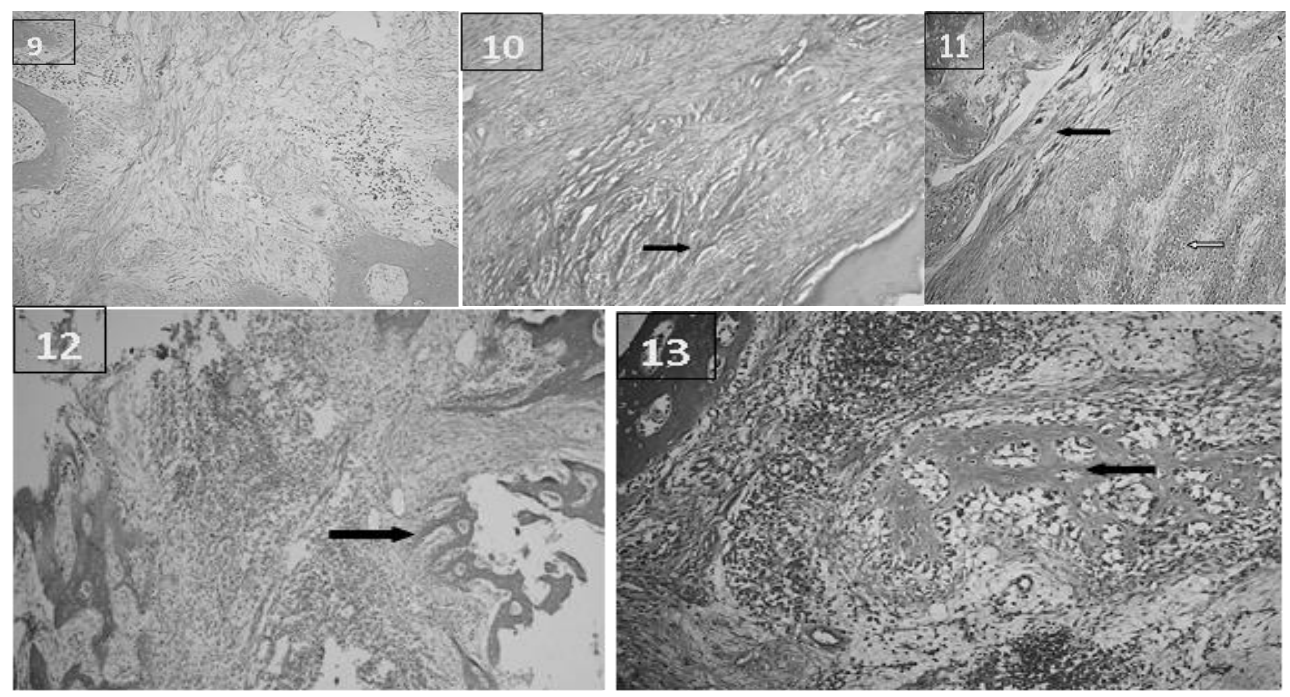

Fig. (9): Dog, group II 4 weeks postoperative, showing moderately dense connective tissue forming the external and internal callus. H\&E, X 40 
Fig. (10): Dog, group I 8 weeks postoperative, showing mature granulation tissue with collagen fibers on the internal surface of the bone at the fracture site (arrow). H\&E, X 40.

Fig. (11): Dog, group II 8 weeks postoperative, showing properly arranged mature granulation tissue (black arrow) and dispersed cartilaginous cells (yellow arrow). H\&E, X 40.

Fig. (12): Dog, group I 12 weeks postoperative, showing small foci of separate bone lamellae at the bone defect (Arrow). H\&E, 40X.

Fig. (13): Dog, group II 12 weeks postoperative, showing bone trabeculae joining each other (arrow) and intermingled with mature granulation tissue H\&E, X 40.

\section{Discussion}

Fracture repair achieved by rigid fixation and perfect alignment of the bone to allow both timely and maximized return to function of the affected area (Baele, 2004).

Exposure of the right femur was done by a skin incision on the lateral aspect of the thigh extending from the greater trochanter till the stifle joint. Similar approach was described by Denny and Butterworth (2000), who preferred this approach to avoid vital structures on the medial aspect and for the ease of manipulation of the femur.

Revealing the femoral diaphysis was carried out by blunt dissection between the vastus lateralis and the biceps femoris muscles to minimize tissue damage. This was in agreement with Hulse and Hyman (1993), who reported that soft tissues around a fracture when minimally disrupted, it provide fragment vascularity and soft tissue envelope.

Self-tapping screws were selected in this study because there was no need to pre drill a pilot hole and it could be removed and reinserted without weakening their hold in the bone. This finding was supported by Gauthier et al. (1992).

The selection of DCP for fixation of femur fracture in this study was attributed to its revolutionary hole design, where it had oval shaped holes providing axial compression by eccentric insertion of the screws of the bone. This feature was realized by Stiffler (2004), who reported that the DCP application can efficiently neutralize compression, shearing, rotational and bending forces on the bone and also provides a stable internal fixation.

In accordance with Stefan and Dimitar (2007) PRP was obtained from the same dog (patient's own blood) to minimize tissue rejection and disease transmission using a 2 step centrifugation, the first was to separate the erythrocytes from platelet poor plasma and the second to separate the PRP from platelet poor plasma. 
In the $1^{\text {st }}$ postoperative day, the local inflammatory signs were pronounced in all. Similar results were obtained by Madison and Martin (1993) who noticed that the inflammatory process reach the peak within $48 \mathrm{hrs}$ after bone injury and completely disappear by one week post fracture.

By the end of the study, animals of group II showed normal attitude during walking with fin lameness at rapid carriage compared to control group that revealed difficulties in walking. Similar findings were reported by Wiltfang et al. (2004), who added that PRP reduce the postoperative discomfort of patients due to accelerated healing.

In radiography of control group, a clear fracture line with mild periosteal callus was present on the $4^{\text {th }}$ week which began bridge the fracture line together with a large endosteal callus on the $8^{\text {th }}$ week. On the $12^{\text {th }}$ week, a declined fracture line with progressed periosteal and endosteal callus. These results were agreed with the results of Sande (1999). In PRP group, a mild to moderate periosteal reaction and progressive endosteal callus was found in group II on the $4^{\text {th }}$ week, a declined fracture line in the $8^{\text {th }}$ week, while on the $12^{\text {th }}$ week, a faint fracture line with dense radiopaque endosteal callus was denoted. These findings were in accordance with Lemos, et al. (2016), who mentioned that, PRP therapy is a safe, nonsurgical, biological treatment of osteoarthritis and bone repair.

Bending of the DCP was noticed in a dog of group II on the $4^{\text {th }}$ week which may be attributed to severe trauma to the fracture site. Similar findings were reported by Epps (1986), who mentioned that plate failure and bending may be due to minor loads in small plates and secondary major trauma in large plates.

Histopathologic examinations on the $4^{\text {th }}$ week revealed a large endosteal callus covering the internal surface of the fractured bone with small periosteal callus in control group. PRP group revealed, moderately dense connective tissue that was forming the external and internal callus. This was in agreement with Gandhi et al. (2006), who noted the presence of granulation tissue in bone defect region, composed of fibroblast, collagen fibers and blood vessels.

On the $8^{\text {th }}$ week, mature granulation tissue with collagen fibers on the internal and to some extent on the external surface of the bone found at the fracture site in control group.This result was matched with those of Thor et al. (2007), who demonstrated that the fibrous and cartilaginous tissues remained unmineralized in the control group. In PRP group the fracture gap was occluded with a dense properly arranged mature granulation tissue and dispersed cartilaginous cells. These results were supported by Servin et al. (2011), who observed 
a cartilaginous center within the cortical bone with the absence of inflammatory cells.

PRP group revealed thin bony trabeculae joining each other intermingled with mature granulation tissue and focal cartilaginous areas on the $12^{\text {th }}$ week. Similar findings were reported by Thor et al. (2007), who observed areas with osteoid tissue (bone tissue being formed), which would call for a longer time for bone maturation.

The results exhibited that PRP slightly improved bone healing. Also, DCP has been considered a suitable method for fixation of femoral diaphyseal fracture in dogs.

\section{References}

Baele, B.S.(2004): Orthopedic Clinical Techniques of Femur Fracture Repair. Clin Tech Small Anim. PRact.; 19: 134 - 150.

Denny, H. R.; and Butterworth, S. J. (2000): The femur. In Denny, H. R.; and Butterworth, S. J.: A Guide to Canine and Feline Orthopedic Surgery (4 $4^{\text {th }}$ Ed.). Blackwell Publishing Company. Pp. 495.

Duncan, D. B. (1955): Multiple range and multiple $F$ tests. Biometrics, 11(2): 1-42.

Eppley, B.L.; Woodell, J.E. and Higgins, J. (2004): Platelet quantification and growth factor analysis from platelet-rich plasma: implications for wound healing. Plast Reconstr. Surg., 114: 15021508.
Epps, C.H. (1986): Complications in orthopaedic surgery. $2^{\text {nd }}$ ed. JB Lippincott publishers, Pp 151-152.

Fox, S.M.; Bary, J. C.; Guerin, S. R.; and Burbridge, H.M. (1995): antebrachial deformities in the dog: treatment with external fixation. J..Small Anim. Pract. 36: 315-330.

Gandhi, A.; Dumas, C.; O'Connor, J.P.; Parsons, J.R. and Lin, S.S. (2006): The effects of local platelet rich plasma delivery on diabetic fracture healing. Bone, 38(4):540-546.

Gauthier, E.; Perren, S.M. and Ganz, R. (1992): Principles of internal fixation. Curr. Orthop., 6(12):220-232.

Hobbenaghi, R.; Mahboob, P.; Saifzadeh, S.; Javanbakht, J.; Yaghoobi, J.; Manesh, Y.; Mortezaee, M.; Touni, S.R.; Hosseini, E.; Aghajanshakeri, S.; Moloudizargari, M. and Javaherypour, S. (2014): Histopathological features of bone regeneration in a canine segmental ulnar defect model. J. Diagnostic Pathology, 59 (9):131-137.

Hulse, D. and Hyman, B. (1993): Fracture biology and biomechanics. In Slatter, D. Textbook of small animal surgery $\left(1^{\text {st }} \quad\right.$ ed $)$. Philadelphia: W.B Saunders, Pp. 1595 - 1603.

Lemos, A.A.; Mello, C.C.; Dos Santos, D.M.; Verri,F.R.;Goiato, M.C. and Pellizzer E.P. (2016): Effects of platelet-rich plasma in association with bone grafts in maxillary sinus augmentation: a systematic review and meta- 
analysis. Int. J. Oral Maxillofac. Surg., 45: 517-525.

Madison, M. and Martin, R. B. (1993): Fracture healing. In Chapman, M. W. (ed.) Operative Orthopaedics. Lippincott, Philadelphia, Pp. 221-228.

Marx, R.E. (2004): Platelet-rich plasma: evidence to support its use. J. Oral Maxillofac. Surg., 62:489496.

Murphy, T.P.; Hill, C.M. and Kapatkin, A.S. (2001): Pullout properties of $3.5 \mathrm{~mm} \mathrm{AO/ASIF} \mathrm{self}$ tapping and cortex screws in a uniform synthetic material and in canine bone. Vet. Surg., 30:253260.

Roe, S.C. (2003): Internal fracture fixation, in Slatter D (ed): Textbook of Small Animal Surgery. Philadlphia, PA, Saunders, 2 (ed 3): Pp $1798-1818$.

Sande, R. (1999): Tibial fracture in cats. Compend Contin Educ Vet Pract; 15: 383-393.

Servin, T.; Reyes, E.J.; Garrido, F.; Flores, G.; Osuna, M. and Rodriguez, F. (2011): Use of a Graft of Demineralized Bone Matrix Along with TGF- $\beta 1$ Leads to an Early Bone Repair in Dogs. J. Vet. Med. Sci., 73(9): 1151-1161. Snedecor, George W. and Cochran, William G.
(1989): Statistical Methods, Eighth Edition, Iowa State University Press.

SPSS (20.0): Command Syntax Reference, Chicago, Illinois, SPSS Inc. 2006.

Stefan, P. and Dimitar, A (2007): Platelet-rich plasma - an accelerator of the secondary stability of immediate loaded implants. Journal of IMAB., 2 (13): 38-40.

Stephan, M. and Perren, S.M. (2002): Evaluation of the internal fixation of long bone fractures. J. Bone surg., 84-B: $1093-1110$.

Stiffler, K.S. (2004): Internal fracture fixation. Clin. Tech. Small. Anim. Pract., 19 (3): 105-113.

Thor, A.; Franke-Stenport, V.; Johansson, C.B. and Rasmusson, L. (2007): Early bone formation in human bone grafts treated with platelet-rich plasma: preliminary histomorphometric results. Int. J. Oral Maxillofac Surg., 36:11641171.

Wiltfang, J.; Kloss, F.R.; Kessler, P.; Nkenke, E.; Schultze-Mosgau, S. and Zimmermann, R. (2004): Effects of platelet-rich plasma on bone healing in combination with autogenous bone and bone substitutes in critical-size defects. Clin. Oral Implants Res., 15(2):187-93. 
دور البلازما الغتية بالصفائح على إلتئام كسر عظمة الفخذ المستحدث المثبت

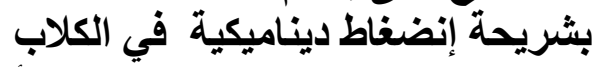

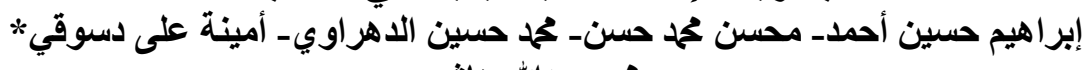

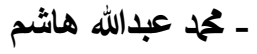

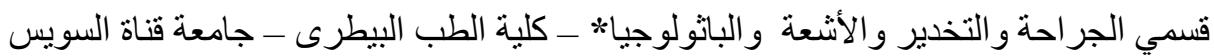

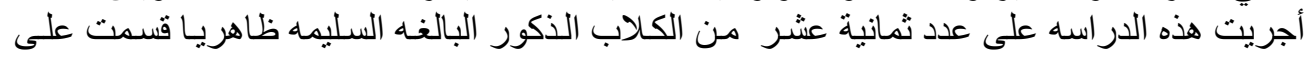

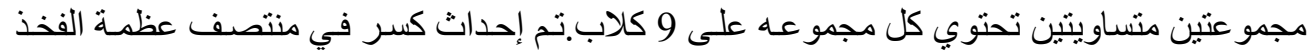

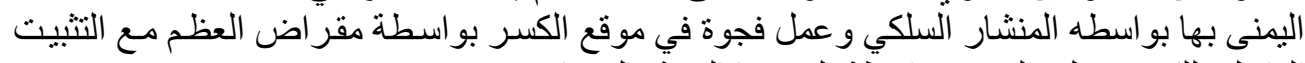

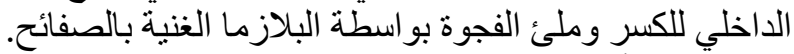

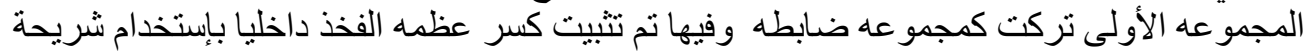

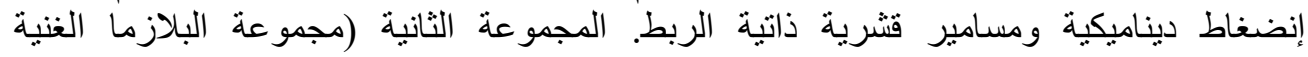

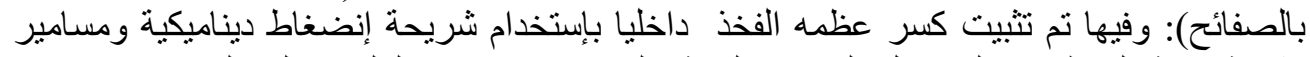

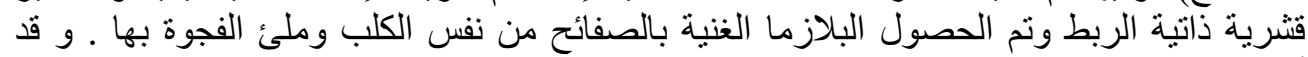

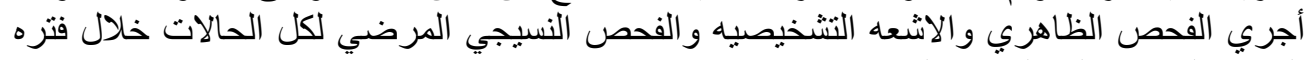

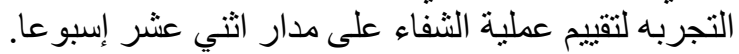
وقد أظهرت الدراسه أن إستخدام البلازما الغنية بالصفائح طريقة آمنة للمساعدة قليلا على إلتئام الكسور. 